\title{
LiABILITY FOR SUSPENSION/DISCONTINUATION, ABANDONMENT AND REClaMATION IN ALBERTA: AN UPDATE
}

\author{
Nickie VlaVIaNOS*
}

This article outlines the current regulatory framework for suspension/discontinuation. abandonment, and reclamation liabilities in Alberta. The focus is on the recent amendments introduced by the Energy Statutes Amendment Act, 2000. First, jurisdictional issues that arise regarding these liabilities are discussed. Then the current liability regime for the suspension and abandonment of oil and gas wells and other upstream facilities is reviewed. A similar review is conducted of liabilities associated with discontinuing and abandoning pipelines in Alberta. The liability regime applicable to the reclamation of wells, facilities, and pipelines is then considered. The article concludes with a review of the Energy Statutes Amendment Act's, 2000 amendments to the Orphan Fund.
Cet article décrit le cadre réglementaire actuel régissant la suspension ou le désistement. l'abandon d'obligations ou les obligations d'assainissement en Alberta. Le point de mire en sont les récents amendements proposés da la Energy Statutes Amendment Act, 2000. Tout d'abord, les questions de juridiction résultant de ces obligations font l'objet d'une discussion. Puis le régime d'obligation actuel qui régit la suspension ou l'abandon de puits pétroliers ou gaziers et d'autres installations en amont est revu. Une etude semblable est faite des obligations liées au désistement et à l'abandon de gazoducs en Alberta. L'article se termine par une revue des amendements à la fondation orpheline de la Energy Statutes Amendment Act, 2000.

\section{TABLE OF CONTENTS}

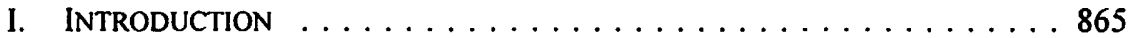

II. JURISDICTIONAL ISSUES $\ldots \ldots \ldots \ldots \ldots \ldots \ldots \ldots \ldots 6$

III. LIABILITY FOR SUSPENSION AND ABANDONMENT

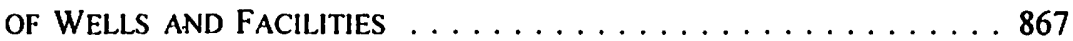

A. DUTIES TO SUSPEND AND ABANDON $\ldots \ldots \ldots \ldots \ldots \ldots 86$

B. WHEN AND HOW TO SUSPEND AND ABANDON .......871

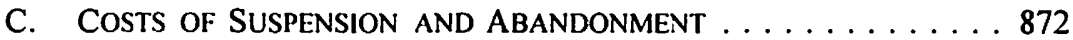

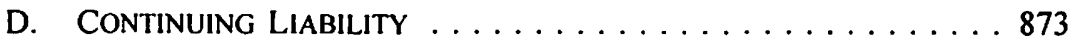

E. SUSPENSION AND ABANDONMENT BY THE EUB $\ldots \ldots \ldots .873$

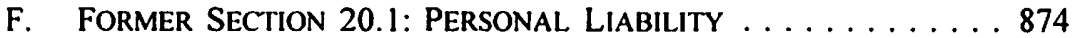

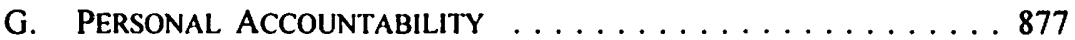

IV. LIABILITY FOR DISCONTINUATION AND

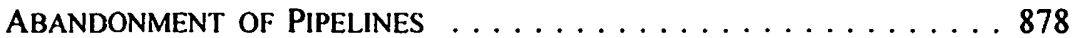

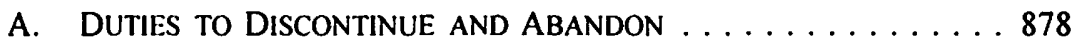

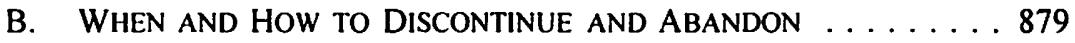

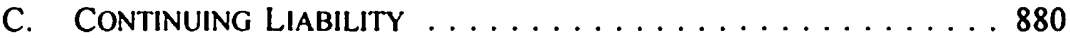

D. Discontinuation and ABandonment by the EUB $\ldots \ldots 880$

E. COSTS OF DisContinUATION AND ABANDONMENT $\ldots \ldots \ldots 880$

F. PERSONAL ACCOUNTABILITY $\ldots \ldots \ldots \ldots \ldots \ldots \ldots 1$

Sessional Instructor, Faculty of Law, University of Calgary. Project Researcher for the Canadian Institute of Resources Law and the Alberta Civil Liberties Research Centre at the University of Calgary on a joint project considering human rights and resource development issues. An earlier version of this article was presented at a L.E.S.A. seminar entitled "Oil and Gas Law: Selected Topics" (Calgary, Alberta, 23 November 2000). Thanks to Professor Nigel Bankes, Faculty of Law, University of Calgary, for asking me to participate. 
V. LIABILITY FOR RECLAMATION OF WELLS,

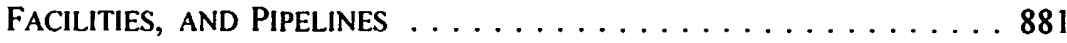

A. Duty to Reclaim Pursuant to the EPEA ....... 881

B. The Practice in Alberta ............... 883

C. WHEN AND How to ReCLAIM SPECIFIEd LAND . . . . . . 885

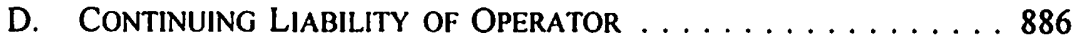

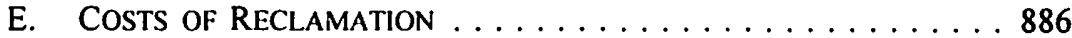

VI. EXPANSION OF ORPHAN FUND $\ldots \ldots \ldots \ldots \ldots \ldots \ldots \ldots \ldots 88$

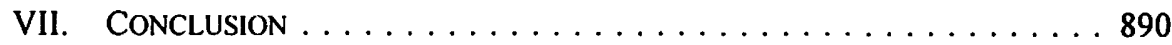

\section{INTRODUCTION}

On June 30, 2000, the Energy Statutes Amendment $A c t, 2000^{1}$ was proclaimed in force. Bill 13 made some significant changes to the environmental liability regimes that govern the exploration and production of oil and gas in Alberta. In particular, it established clear duties in regard to the suspension/discontinuation of wells, facilities, and pipelines in the province. Significant changes were also made to the liability regimes governing the abandonment and reclamation of wells, facilities, and pipelines. Throughout, the focus of these changes is upon holding parties accountable for the liabilities associated with their operations.

Where no responsible party is available, the Orphan Fund may be available to cover the relevant costs. As originally established, the Fund covered only the costs associated with the abandonment of oil and gas wells in Alberta. Pursuant to Bill 13, however, the Fund has now been expanded beyond wells to include certain oil and gas production and processing facilities as well as pipelines. Moreover, it has been expanded beyond abandonment to include the costs of suspension/discontinuation and reclamation. The identification and imposition of liability upon responsible parties is fundamental to minimizing the financial risks to this expanded Fund. ${ }^{2}$

This article outlines the current regulatory framework for suspension/discontinuation, abandonment, and reclamation liabilities in Alberta. The focus throughout is on the recent amendments introduced by Bill 13. Part II of this article provides a brief discussion of some of the jurisdictional issues that arise regarding these liabilities in Alberta. In Part III the current liability regime for the suspension and abandonment of oil and gas wells and other upstream facilities is reviewed. It highlights who is responsible for carrying out suspension and abandonment as well as who is liable for paying the costs of these activities. Part IV conducts a similar review for liabilities associated with discontinuing and abandoning pipelines in the province. Part $\mathrm{V}$ of this article then considers the liability regime applicable to the reclamation of wells, facilities, and pipelines in Alberta. Again, the focus is upon who is liable for carrying out reclamation and paying for its costs and

S.A. 2000. c. 12 [hereinafter Bil! /3].

The amendments introduced by Bill 13 implement most of the Report and Recommendations of the Orphan Facilities. Pipelines and Reclamation Subcommillee (July 1996, revised October 1997), (EUB); see also online: EUB <www.eub.ggov.ab.ca/bbs/programs/lmp/mp.htm> (date accessed: 3 October 2001). 
any relevant changes introduced by Bill 13 . Where none of the parties responsible for suspension/discontinuation, abandonment, and reclamation are available or solvent, the Orphan Fund may be available to cover the relevant costs. Part VI reviews the Bill /3 amendments in this regard.

\section{JURISDICTIONAL ISSUES}

The duties to suspend/discontinue, abandon, and reclaim oil and gas wells, facilities, and pipelines are distinct legal obligations under the current Alberta regulatory regime. The first two, those of suspension/discontinuation and abandonment, arise under the Oil and Gas Conservation $\mathrm{Act}^{3}$ and the Pipeline $\mathrm{Act},{ }^{4}$ which are administered and enforced by the Alberta Energy and Utilities Board ("EUB"). The statutory duty to reclaim oil and gas wells, facilities, and pipelines is set forth in the Alberta Environmental Protection and Enhancement Act, administered and enforced by Alberta Environment ("AENV").

Under the EPEA, reclamation is defined very broadly in s. $1(\mathrm{ccc})$ to mean

any or all of the following:

(i) the removal of equipment or buildings or other structures or appurtenances;

(iii) the decontamination of buildings or other structures or other appurtenances, or land or water;

(iv) the stabilization, contouring, maintenance, conditioning or reconstruction of the surface of land;

(v) any other procedure, operation or requirement specified in the regulations.

Defined so broadly, the term reclamation in the EPEA describes the entire process from abandoning a well, facility, or pipeline to returning the land to equivalent capability. In other words, it includes activities amounting to abandonment, decontamination, and surface land reclamation. ${ }^{6}$

Given the potential for overlap in the jurisdiction of the EUB and AENV as a result of this definition, these two regulatory bodies have entered into a Memorandum of Understanding ("MOU") to clarify their roles and responsibilities when upstream oil and gas facilities are suspended, abandoned or reclaimed. Responsibilities of the EUB include: (a) ensuring that "inactive upstream oil and gas facilities are properly suspended and left in a safe and stable state"; (b) ensuring that "inactive upstream oil and gas facilities are properly abandoned and dismantled and that free produced liquids and structural concrete are removed"; and (c) conducting inspections and taking enforcement action when

R.S.A. 1980 , c. $0-5$ [hereinafter $O G C A$ ].

R.S.A. 1980 , c. P-8.

S.A. 1992. c. E-13.3 [hereinafter EPEA].

See, for example, "Memorandum of Understanding Between AEP and EUB on Suspension, Abandonment, Decontamination, and Surface Land Reclamation of Upstream Oil and Gas Facilities" attached to, "Suspension, Abandonment, Decontamination, and Surface Land Reclamation of Upstream Oil and Gas Facilities" (26 March 1998), IL 98-02 (EUB). 
necessary. AENV's responsibilities include: (a)ensuring decontamination of impactedsites to meet established remediation objectives; (b) developing surface land reclamation requirements and ensuring that these requirements are met; (c) issuing reclamation certificates; and (d) conducting inspections and taking enforcement action as necessary. ${ }^{7}$

In order to bring the costs of reclamation into the expanded Orphan Fund, Bill 13 introduced a number of provisions dealing with reclamation into the $O G C A$ and the Pipeline Act. Along with others discussed below, Bill 13 added (or amended) the following provisions concerning reclamation:

(a) s. 10(a.2) of the OGCA authorizes the EUB to make regulations for the provision of deposits and other security to guarantee the proper and safe reclamation of wells and facilities (as well as their proper and safe suspension and abandonment); ${ }^{8}$

(b) s. 10(g.03) of the OGCA empowers the EUB to make regulations respecting suspension, abandonment and reclamation costs in respect of wells and facilities; ${ }^{9}$ and

(c) s. 3(1)(e.2) of the Pipeline Act authorizes the EUB to make regulations respecting discontinuation, abandonment and reclamation costs in respect of pipelines. ${ }^{10}$

Despite these changes, ensuring reclamation of oil and gas sites remains the jurisdiction and responsibility of AENV. The Bill 13 amendments to the OGCA and the Pipeline Act relate to reclamation costs only. The regulation of reclamation generally remains under AENV authority. Through Bill 13, however, the intention was to provide the energy industry with a "one-window service" for the collection of abandonment and reclamation security deposits by the EUB, as well as the annual Orphan Fund levy. The EUB's administration of the expanded Orphan Fund also ensures a "one-window service" for claims against the Fund for suspension, abandonment, and reclamation costs."

\section{LIABILITY FOR SUSPENSION AND ABANDONMENT OF WELLS AND FACILITIES}

The regulatory framework for the suspension and abandonment of wells and facilities is set out in the OGCA and the Oil and Gas Conservation Regulations. ${ }^{12}$ Although definitions for suspension and abandonment could be found elsewhere prior to Bill $13,^{13}$

Ibid.

Substituted by Bill 13, supra note 1, s. 1(5)(a)(ii).

Substituted by Bill 13, ibid., s. 1(5)(a)(iv).

Substituted by Bill 13, ibid., s. 2(3)(b).

"Important New Petroleum Industry Clean Up Legislation - CAPP. SEPAC and EUB Announce Expanded Orphan Program" (28 June 2000), NR 2000-30 (EUB).

Alta. Reg. 151/71 [hereinafter OGCR].

See, for example, supra note 6 . 
explicit definitions for both have now been added to the $O G C A .{ }^{14}$ These definitions mirror those previously adopted and reflect the general understanding of these terms in the oil and gas industry.

Section 1(1)(t.01) of the OGCA defines suspension as "the temporary cessation of operations at a well or facility in the manner prescribed by the regulations." It "includes any measures required to ensure that the well or facility is left in a safe and secure condition." As clarified by the MOU between AENV and the EUB, suspension does not require the well or facility to be rendered permanently incapable of its licensed use. Rather, it requires that the operation be left in a safe and stable state during this period of suspension as prescribed by the appropriate regulations and EUB guidelines. ${ }^{15}$

According to s. $1(1)(a)$ of the $O G C A$, abandonment means "the permanent dismantlement of a well or facility in the manner prescribed by the regulations and includes any measures required to ensure that the well or facility is left in a permanently safe and secure condition." More specifically, abandonment has been defined as including: (a) "leaving downhole or subsurface structures in a permanently safe and stable condition in accordance with EUB requirements"; (b) "the removal of associated equipment and structures"; (c) "the removal of all produced liquids"; and (d) "the removal and appropriate disposal of structural concrete."16

\section{A. DUTIES To SUSPEND AND ABandon}

Prior to the proclamation of Bill 13, the OGCA placed a clear duty upon a licensee only with respect to abandoning oil and gas wells. As amended, s. 20.2(1) now includes an obligation on a licensee to both suspend and abandon its wells. ${ }^{17}$ In addition, these obligations now extend beyond oil and gas wells to other upstream facilities. Section 20.2(1) of the $O G C A$ now reads as follows: "Subject to subsection (2), a licensee or approval holder shall suspend or abandon a well or facility when directed by the Board or required by the regulations."

Section I(1) provides the relevant definitions. Licensee has been amended ${ }^{18}$ to include a trustee, and now s. $1(1)(I)$ reads as follows: "'licensee' means the holder of a licence according to the records of the Board, and includes a trustee or receiver-manager of property of a licensee."

Along with licensee, Bill 13 has added a new category of approval holder to s. 20.2(1). ${ }^{19}$ This party is defined in s. 1(1)(a.04) ${ }^{20}$ as the holder of an approval granted under the $O G C A$, any predecessor legislation, or any regulation under any of them. Although a trustee or receiver-manager of an approval holder's property is not expressly

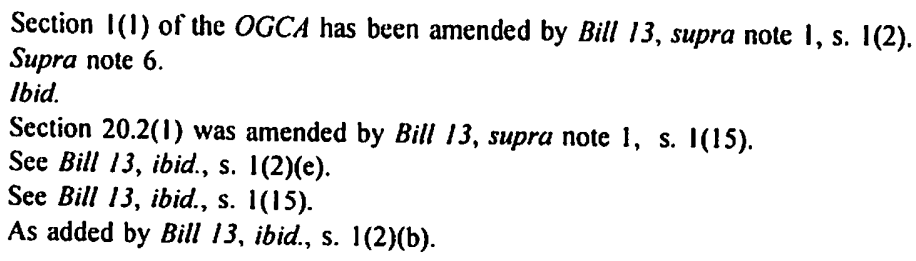

Section I(1) of the OGCA has been amended by Bill /3, supra note I, s. 1(2). Supra note 6.

Ibid.

Section 20.2(1) was amended by Bill 13, supra note 1, s. I(15).

See Bill 13, ibid., s. 1(2)(e).

See Bill 13, ibid., s. 1(15).

As added by Bill 13, ibid., s. 1(2)(b). 
mentioned in the relevant definition, it is likely the EUB will consider both to be included so as to mirror the treatment of licensees. ${ }^{21}$

Beyond oil and gas wells, s. 20.2(1) of the OGCA now extends the statutory duties of suspension and abandonment to most upstream oil and gas facilities. Generally speaking, a facility under the OGCA means "any building, structure, installation, equipment or appurtenance over which the Board [EUB] has jurisdiction and that is connected to or associated with the recovery, development, production, handling, processing, treatment or disposal of hydrocarbon-based resources or any associated substances or wastes."22 More specifically, the definition includes "a battery, a processing plant, a gas plant, an oilfield waste management facility, [and] a central processing facility as defined in the Oils Sands Conservation Regulation." ${ }^{23}$ Explicitly excluded are wells, pipelines, mine sites, or processing plants defined in the $O S C R$, and mine sites or coal processing plants under the Coal Conservation Act. ${ }^{24}$

In addition, a new provision added to the $O G C A$ by $B i l l 13^{25}$ extends the statutory obligations to suspend and abandon beyond wells and facilities. According to s. 20.7, where the $O G C A$ or the $O G C R$ imposes an obligation in respect of "the operation, suspension or abandonment of a well or facility," this obligation also extends to "associated equipment and non-licensed facilities that are located on the site or used in connection with the operation, suspension or abandonment of the well or facility." 26 This provision applies unless such equipment and facilities are exempted by the OGCR.

In sum, a licensee or approval holder has a duty to suspend and abandon both its oil and gas wells and other upstream oil and gas facilities. If the EUB so directs, however, s. 20.2(2)(a) states that "a well or facility must be suspended or abandoned by a working interest participant other than the licensee or approval holder." Moreover, according to s. $20.2(2)(b)$, "a well or facility may be suspended by a working interest participant" with the consent of the EUB. ${ }^{27}$

Some changes to these provisions can be noted. First, prior to the amendments under Bill 13, s. 20.2(2) referred to the working interest participants abandoning a well upon the EUB's direction. The amendment clarifies that the EUB can order a single working interest participant to carry out the suspension or abandonment. The Act does not, however, provide any guidance for how the particular working interest participant will be chosen where there are multiple parties involved in a well or facility.

Under amendments introduced by Bill 13 , oil and gas facilities will now be licensed or require an approval under s. 11.1 of the $O G C A$. See also: "Expanded Orphan Program Implementation" (28 June 2000), GB 2000-17 (EUB); "Retrospective Facility Licensing Program" (24 October 2000), ID 2000-10 (EUB); and "Energy Development Licence Transfer Requirements and Monthly Corporate Licensee Liability Rating" (12 April 2001), ID 2000-11 (EUB).

22 Section I(1)(i.2) of the OGCA as added by Bill 13, supra note I, s. 1(2)(d).

23 Alta. Reg. $76 / 88$ [hereinafter $O S C R$ ].

24 R.S.A. 1980, c. C-14.

is Supra note 1, S. 1(15).

26. Supra note 3.

27 lbid. 
A second change to s. 20.2(2) deals with suspension and abandonment with the consent of the Board. Prior to Bill 13, s. 20.2(2) provided for the abandonment by the other working interest participants in the well with the consent of the Board. As amended, the relevant section speaks only to suspension (and not abandonment) by a working interest participant with the consent of the Board. The rationale for this change is not clear.

For purposes of the suspension and abandonment provisions in the $O G C A$, a working interest participant is defined in s. $1(1)(y .2)$ as "a person who owns a beneficial or legal undivided interest in a well or facility under agreements that pertain to the ownership of that well or facility." The former reference to control has now been removed from this definition. ${ }^{28}$

Certain parties may still be deemed to be working interest participants under the $O G C A$, however. Section $20.6^{29}$ provides that the EUB may deem a person to continue to be a working interest participant where:

(a) a transaction occurs that results in a person no longer being a working interest participant in a well or facility,

(b) the successor working interest participant is a person other than the licensee of the well or facility, and

(c) the successor working interest participant fails to pay its proportionate share of suspension, abandonment or reclamation costs.

Along with these, one of the following circumstances must coexist:

(d) in the case of a well, the transaction occurred after the well ceased to meet the economic limit test set out in the regulations, or

(e) in the case of a facility, the transaction occurred after the facility ceased operation or after the facility has throughput that is less than the rate prescribed in the regulations as sufficient to warrant deeming the facility to be active. ${ }^{30}$

Along with adding facilities and suspension and reclamation costs to this deeming provision, Bill 13 made several other noteworthy changes. First, unlike the language of its predecessor, s. 20.6 of the $O G C A$ is discretionary. Rather than stating that a party is deemed to continue to be a working interest participant once certain circumstances are met, s. 20.6 now states that such a party may be so deemed by the Board. Second, the new provision is more qualified in its application. Previously, the section applied broadly to transactions that occurred after a well ceased producing in paying quantities. With the controls all or part of a beneficial or legal undivided interest in a well under agreements that pertain to the ownership of that well" [emphasis added]. Prior to Bill 13 , s. 20.1 of the OGCA also included persons with actual control of a corporation into the definitions of "licensee" and "working interest participant" for purposes of the well abandonment provisions. As will be discussed below, this section has been repealed.

:" As substituted by Bill 13, supra note I, s. I(15).

"1' As set out in OGCA, supra note 3, ss. 20.6(d) and (e). 
economic limit test to be introduced under the new section, the scope of its application will be more clearly defined.

In summary, the $O G C A$ imposes liability for suspending and abandoning oil and gas wells and facilities upon the following parties:

- the licensee or approval holder of the well or facility;

- a receiver-manager or trustee of property of the licensee (or approval holder?);

- a working interest participant other than the licensee or approval holder upon the Board's direction, or with its consent in the case of suspension; and

- a prior working interest participant that is deemed to continue to be a working interest participant under section 20.6 .

\section{B. When AND How to SUSPEND AND ABANDON}

As noted above, s. 20.2(1) of the $O G C A$ provides that a licensee or approval holder must suspend or abandon a well or facility when directed by the Board or when required by the regulations. Section 20.2(3), added to the $O G C A$ by Bill $13,{ }^{31}$ now clarifies that the EUB may order a well or facility to be suspended or abandoned where it considers this necessary to protect the public or the environment.

Regarding when suspension or abandonment is required by the regulations, the $O G C R$ currently speaks only to suspension and abandonment of wells. New and revised requirements respecting the suspension and abandonment of facilities are expected shortly. ${ }^{32}$

For suspension of wells, s. 3.020(1) of the OGCR provides that a licensee must suspend a well "within twelve months after the last producing or injection operations have occurred." There are two exceptions, however. Where "the well is produced only to supply a seasonal market" or "the well is classed as an observation well," this requirement does not apply. Section 3.020(1) also provides that the licensee shall "suspend a well, in accordance with the requirements established by the Board [EUB]." These requirements have been set forth in two interim directives issued by the EUB. ${ }^{33}$

With respect to well abandonment, s. $3.068(1)$ of the $O G C R$ requires a licensee to abandon a well:

$3 \quad$ Supra note I. s. I(15).

32 "Expanded Orphan Program Implementation" (28 June 2000), GB 2000-17 (EUB).

"3 "Suspension Guidelines for Inactive Wells" (20 September 1990), ID 90-04 (EUB) and "Suspension Guidelines Compliance Schedule and Application Requirements for Inactive Wells" (12 July 1991), ID 91-05 (EUB). 
(a) on the termination of the mineral lease, surface lease or right of entry,

(b) if the Board [EUB] notifies the licensee that in the opinion of the Board the well may be an environmental or a safety hazard,

(c) if the licensee is dissolved or the corporate registry status of the licensee is struck or rendered liable to be struck under any legislation governing corporations,

(d) if the licensee has suspended a well in contravention ... [of the regulations], or

(e) when so ordered by the Board. ${ }^{34}$

On the question of how the well is to be abandoned, s. 3.068(2) of the $O G C R$ provides that abandonment operations must be conducted "in accordance with Guide G20 'Well Abandonment,' published by the Board [EUB]."

\section{Costs of SUSPENSION AND ABANDONMENT}

Prior to Bill 13, the $O G C A$ provided for the allocation of costs among working interest participants in regard to well abandonment costs only. Pursuant to s. 20.5(1) of the amended $O G C A,{ }^{35}$ both suspension and abandonment costs "must be paid by the working interest participants in accordance with their proportionate share in the well." Similarly, working interest participants are obligated to pay the suspension and abandonment costs for facilities in accordance with their proportionate share in the facility. ${ }^{36}$ Section 1(1)(s.01) of the OGCA defines proportionate share as "the percentage share equal to the participant's undivided interest in the well or facility."

Where a well or facility has been suspended or abandoned by a licensee, approval holder, working interest participant or agent, the EUB may determine the suspension and abandonment costs on the application of the person who conducted the suspension or abandonment. Unlike its predecessor, s. 20.5(2) of the $O G C A^{37}$ now clarifies that once such costs are determined, the EUB must allocate them among the working interest participants in accordance with their proportionate share in the well or facility. The EUB must also prescribe a time for payment. ${ }^{38}$

Along with its share of suspension and abandonment costs, a working interest participant may also be liable to pay a penalty of 25 percent of those costs. Pursuant to s. 20.5(3) of the $O G C A,{ }^{39}$ a working interest participant that fails to pay its share of costs within the period of time prescribed by the EUB must, unless otherwise directed, pay a penalty equal to 25 percent of its share of suspension or abandonment costs. Both

4 Supra note 12.

3 As amended by Bill 13, supra note 1, S. I(15).

36. Section 20.5 of the $O G C A$ also requires working interest participants to pay for the reclamation costs of wells and facilities. This will be discussed in Part $\mathrm{V}$ of this article.

37 As amended by Bill 13, supra note 1, s. 1(15).

38 The criteria for applying for costs orders against reluctant working interest participants are currently set out in "Abandonment Costs Order Application Reimbursement Application Abandonment Fund" (24 January 1995), IL 95-03 (EUB), which remains in effect. Since it refers only to well abandonment costs orders, however, this document will likely be updated in the near future to reflect the recent changes to the $O G C A$. 
this penalty and its share of costs constitute a debt payable by the working interest participant to the party that carried out the suspension or abandonment. ${ }^{40} \mathrm{~A}$ certified copy of the EUB's order determining the costs and penalty (and the allocation of those costs to each working interest participant in the well or facility) may, pursuant to s. 20.5(6), be filed in the Court of Queen's Bench. Once filed, the order may be entered as a judgment of the Court and enforced as such.

\section{Continuing Liability}

Whatever uncertainty may have existed before, the $O G C A$ is now clear that abandonment of a well or facility does not relieve a party from either its duty to conduct further abandonment or its obligation to pay the costs of such work. Bill 13 has added a new section to the $O G C A^{41}$ which states:

20.4 Abandonment of a well or facility does not relieve the licensee, approval holder or working interest participant from responsibility for the control or further abandonment of the well or facility or from the responsibility for the costs of doing that work.

Thus the liability upon licensees, approval holders, and working interest participants to carry out abandonment and to pay for its costs continues indefinitely. This is so even if the abandonment operations were conducted in accordance with current requirements.

\section{E. SUSPENSION AND ABANDONMENT by THE EUB}

Prior to Bill 13, the power of the EUB to enter a well site and carry out suspension or abandonment operations was found in a general provision (s. 92) that authorized the EUB to do whatever it considered necessary where there had been a failure to comply with an order, direction, or requirement of the Board. Through the addition of s. 20.3 to the $O G C A$ by Bill $13,^{42}$ the EUB's power in this regard is now located alongside the suspension and abandonment provisions of the $\mathrm{Act}$. Further, this section now explicitly extends the Board's powers to suspend or abandon beyond wells to other oil and gas facilities.

Pursuant to s. 20.3, if the EUB is of the view that a well or facility has not been "suspended or abandoned in accordance with a direction of the Board or the regulations, the Board [EUB] may: (a) authorize any person to suspend or abandon the well or facility, or (b) suspend or abandon the well or facility on the Board's own motion." ${ }^{13}$ Where a well or facility is suspended or abandoned by the EUB or its authorized representative, s. 20.5(2)(b) empowers the EUB to determine the relevant suspension and abandonment costs. The EUB must then allocate these costs to the working interest participants in the well or facility according to their proportionate share and prescribe a time for payment. Together with any 25 percent penalty, these costs constitute a debt payable to the EUB

See $O G C A$, supra note 3 , s. 20.5(4).

See Bill 13, supra note 1, s. I(15).

Ibid.

OGCA, supra note 3. 
pursuant to section 20.5(5). Once the costs order is filed with the Court of Queen's Bench, it may be enforced as a judgment of that Court.

In regard to carrying out suspension or abandonment, Bill 13 has expanded s. 92.1(1) of the $O G C A^{44}$ to allow access to any structure on the land for purposes of carrying out the suspension or abandonment. Where the EUB conducts the suspension or abandonment, s. 93(1) of the OGCA empowers it to sell equipment or material found on the site. Bill 13 has amended this provision to include facilities and to provide for how the EUB must apply any money received from the sale or disposal. ${ }^{45}$

In addition to this debt collection mechanism, the $O G C A$ provides the EUB with liens in certain property owned by a party who is indebted to the Board and with the power to enforce such liens through a garnishment process. Although this already existed prior to Bill 13, amendments to s. 93.1 have clarified the procedure and have expanded the scope of the EUB's liens to cover the facilities and pipelines of the debtor. ${ }^{46}$

\section{F. Former Section 20.1: Personal Liability}

Prior to Bill 13, s. 20.1 of the $O G C A$ included a person with actual control of the corporation (including a person referred to in s. 2(2) of the Business Corporations $\mathrm{Act}^{47}$ ) in the definitions of licensee and working interest participant for purposes of well abandonment liability. In effect, this provision could result in the personal liability of directors, officers, or shareholders of a corporation for well abandonment and the costs thereof. Section 20.1 was, however, repealed by Bill $13 .{ }^{48}$

A number of policy reasons appear to have led to the repeal of s. 20.1. In essence, it was found to be an ineffective enforcement mechanism and was difficult to administer. Problems and concerns with pursuing the persons in control of a corporation included: (a) the fact that the person in control was often not easily identifiable; (b) even if identifiable, often there were no significant assets left in that person's hands; (c) pursuing such persons could lead to time-consuming and costly hearings and court proceedings that would only serve to delay necessary abandonment operations; and (d) it was not perceived to be a significant enough deterrent. ${ }^{49}$

Although this section has been repealed, it may continue to have some application. For files on which abandonment orders were issued prior to June 30, 2000 (the proclamation date of Bill 13), the former provisions of the $O G C A$ continue to apply based on the argument that liability crystallized at the time the order was issued. For abandonment

4 Supra note 1, s. 1(26).

45 Supra note 1, s. 1(27).

th Supra note I, s. 1(28).

47 S.A. 1981. c. B-15.

4x Supra note I, s. 1(14).

w These policy reasons were discussed by EUB representatives at a Canadian Bar Association Environmental Law Subsection Meeting on the Expansion of the Orphan Program (Calgary, Alberta, I November 2000). 
orders issued after June 30,2000 , however, the new provisions of the OGCA will apply. ${ }^{\text {so }}$

Where former s. 20.1 of the $O G C A$ continues to apply to liability issues in regard to well abandonment, reference should be made to the following decision of the EUB: South Alberta Energy Corp., Greg Justice, 693040 Alberta Ltd., and Marc Dame: Review of Abandonment Costs Order No. ACO 98-l.51 In that case, the EUB had issued an abandonment costs order (ACO 98-1) to recover its costs for abandoning a number of wells, pipelines, and batteries licensed to South Alberta Energy Corp. ("SAEC"). Along with SAEC, the costs order named Greg Justice ("Justice"), 693040 Alberta Ltd. ("693040") and Marc Dame ("Dame") as persons in control of SAEC. These three parties requested the Board to review its decision to name them in ACO 98-1 pursuant to s. 43 of the Energy Resources Conservation Act. ${ }^{52}$

The facts can be briefly summarized as follows. In June and September 1995, the EUB issued a number of well abandonment orders to SAEC as licensee of the wells. On October 31, 1995, Justice purchased 100 percent of the shares in SAEC, thus becoming its sole shareholder and director. Shortly thereafter Justice transferred the SAEC shares to another corporation, South Alberta Energy Group ("SAEG"), in which he was also the sole shareholder and director. More abandonment orders were issued by the EUB to SAEC after this time. On August 30, 1996, a corporate transaction that involved SAEG selling 100 percent of its SAEC shares to 693040 was executed by Justice on behalf of SAEG and by Dame on behalf of 693040 as its director and sole shareholder. As SAEC failed to comply with the abandonment orders within the specified time, the EUB ultimately completed the work on its own initiative. Final abandonment operations were completed in June 1999.

On the evidence the Board concluded that the agreement of August 30, 1996, between 693040 and SAEG was terminated by mutual agreement of the parties on October 4 , 1996. For the period prior to October 4, 1996, the Board held that it was not possible to impute liability to Dame and 693040 as persons in control of SAEC solely on the basis of the agreement. The EUB stated with respect to s. 20.1 of the OGCA:

Section 20.1 must be read broadly, as the plain words have a wide meaning. The section and its companion sections provide that any person exercising actual control of a licensee or working interest participant may be liable for abandonment costs. Certainly, the existence of a binding agreement evidencing the transfer of ownership and control may establish the fact of effective actual control required by Section 20.1, but it is not the only indicia of such control. Real. effective, and practical control over a company's business affairs will amount to control as contemplated in Section 20.1 and may exist in a wide variety of settings and arrangements. Control is ultimately the power to direct the business of a

Legal Oil \& Gas Lid., Charles W. Foster, and Tartan Energy Inc. Review of Abandonment Order No. AD98-10 (13 February 2001) D2001-11 [hereinafter Legal Oil and Gas Lid.]. Where the EUB has carried out the abandonment and an abandonment costs order is at issue, the applicable legisiation will be that which was in effect at the time the original abandonment order was issued: ibid.

si

s2 2000-5I (17 July 2000). See also Legal Oil and Gas Lid., ibid.

R.S.A. 1980 , c. E-11. 
company and make decisions that will be complied with and acted upon by a company. Each case must be reviewed on its own facts and circumstances in order to determine the entity effectively exercising this authority. ${ }^{53}$

In the Board's view, at the time of the issuance of ACO 98-1, it was Justice who was the person in actual control of SAEC. He was the person who controlled the majority of voting shares pursuant to s. 2(2) of the Business Corporations Act and he "exercised the power to direct the business of SAEC and made decisions that were complied with and acted upon by SAEC throughout the time period in question." 54

In response to Justice's request that SAEC's previous owners share in the responsibility for the abandonment costs, the Board noted that when Justice purchased SAEC in 1995 he became the licensee and a working interest participant for purposes of s. 20.1 of the $O G C A$. According to the EUB, "that section prevents the Board from naming previous working interest participants in abandonment cost orders if the current working interest participant is the licensee of the facilities in question." 55 As Justice was a successor working interest holder and licensee of the facilities, the EUB concluded that it was precluded from naming the previous owners of SAEC in any abandonment costs order issued against SAEC. ${ }^{56}$ In the result, the EUB directed that both 693040 and Dame be struck from ACO 98-1. Liability for the well abandonment costs (totalling about $\$ 1.5$ million) was imposed solely upon Justice.

Leave to appeal the EUB's decision to the Court of Appeal was granted to Justice on September 28, 2000. ${ }^{57}$ The questions upon which leave was granted are the following:

(a) was the allocation by the Board of the abandonment costs in question among working interest participants as mandated by [former] s. 20.3(1) of the $O G C A$ ?;

(b) did the Board err in holding that [former] s. 20.1 or [former] s. 20.4(2) of the $O G C A$ prevented it from allocating abandonment costs to previous working interest participants?;

(c) did the Board err in holding that Justice was a person in control of the licensee when he held no shares in the licensee?; and

(d) did the Board err in determining the relevant time for "control" of a licensee or working interest participant for the purposes of making an abandonment costs order?

Undoubtedly, the results of this appeal will be of broad significance to issues relating to liability for abandonment, even beyond those specific to former s. 20.1 of the OGCA.

Supra note 51 at 11.

Ibid. at 16.

Ibid. at II.

Ibid.

Justice v. Alberta (EUB), [2000] A.J. No. 1167 (C.A.), online: QL (AJ). 


\section{G. Personal accountability}

Although personal liability for abandonment and its costs has been removed with the repeal of s. 20.1 , Bill 13 has added a new section to the $O G C A^{58}$ that allows for a different kind of personal accountability. Section 95.1 authorizes the EUB to name an individual as being accountable for the actions of a seriously non-compliant licensee (or approval holder) and to restrict or control the activities of any licensee (or approval holder) with which that individual is (or becomes) involved.

Where a licensee, approval holder, or working interest participant (a) contravenes or fails to comply with an EUB order, or (b) has an outstanding debt to the EUB (or to the account of the Orphan Fund) in respect of suspension, abandonment, or reclamation costs, s. 95.1(1) authorizes the EUB to make a declaration where it is in the public interest to do so. This declaration will set out the "nature of the contravention, failure to comply or debt" and name "one or more directors, officers, agents or other persons who in the Board's opinion were directly or indirectly in control of the licensee, approval holder or working interest participant at the time of the contravention, failure to comply or failure to pay." Before making such a declaration, s. 95.1(2) requires the EUB to give written notice of its intention to do so to the persons affected and to allow them "at least 10 days to show cause as to why the declaration should not be made."

Section $95.1(3)$ reads as follows:

Where the Board makes a declaration under subsection (1), the Board may. subject to any terms and conditions it considers appropriate.

(a) suspend any operations of a licensee or approval holder under this Act or a licensee under the Pipeline Act,

(b) refuse to consider an application for an identification code, ${ }^{5 \%}$ licence or approval from an applicant under this Act or the Pipeline Act,

(c) refuse to consider an application to transfer a licence or approval under this Act or a licence under the Pipeline $\mathrm{Act}$,

(d) require the submission of abandonment and reclamation deposits in an amount determined by the Board prior to granting any licence, approval or transfer to an applicant, transferor or transferee under this Act, or

5.) Section I(10) of Bill 13. supra note I. added ss. 15.1 and 15.2 to the $O G C A$ relating to the issuance of identification codes and the imposition of terms and conditions upon those who hold them. Section 15.1 (1) states that "no person shall apply for a licence or approval under the OGCA unless that person holds a subsisting identification code issued under this section." See also: "Licence Eligibility and Qualifications for Potential Licensees and Agents" (2l September 2000), ID 2000-07 (EUB). 
(c) require the submission of abandonment and reclamation deposits in an amount determined by the Board for any wells or facilities of any licensee or approval holder,

where the person named in the declaration is the licensee, approval holder, applicant, transferor or transferee referred to in clauses (a) to (e) or is a director, officer, agent or other person who, in the Board's opinion, is directly or indirectly in control of the licensee, approval holder, applicant, transferor or transferee referred to in clauses (a) to (e). ${ }^{60}$

Pursuant to s. 95.1(4), s. 95.1 "applies in respect of a contravention, failure to comply or debt whether the contravention, failure to comply or debt arose before or after the coming into force of this section."

This sweeping provision that effectively pierces the corporate veil was believed to be necessary for a number of reasons. According to the EUB, some licensees have shown a blatant disregard for regulatory requirements and directions given by the Board. The costs to the EUB of managing the risk these licensees represent to the environment, the public, and the Orphan Fund is significant. Further, the problems associated with seriously noncompliant companies often continue with different companies, which then apply for licences or for transfers of licences. As long as the non-complying individuals are involved, these companies continue to represent a high risk to the environment, the public, and the Orphan Fund. It was thought that this risk can only be properly managed by restricting or controlling the activities of the licensee or approval holder. ${ }^{61}$

Given these policy objectives, the provisions of $\mathrm{s} .95 .1$ will be applied based on the amount or type of risk the individual and the company represent. For example, suspension of operations would be ordered if there is strong evidence that the company, under the control of a particular individual, represents a public safety risk. ${ }^{62}$

\section{LIABILITY FOR DISCONTINUATION AND ABANDONMENT OF PIPELINES ${ }^{63}$}

\section{A. Duties to Discontinue ANd Abandon}

With few exceptions, the discontinuation and abandonment of all pipelines in Alberta is governed by the Pipeline Act under the administration of the EUB. Pursuant to s. 1(1)(a.2) of that $A c t,{ }^{64}$ " "'discontinuation' means the temporary deactivation of a pipeline or part of a pipeline." Section 1(1)(a) defines abandonment as "the permanent deactivation

OGCA, supra note 3.

61

Ibid.

For a discussion of some of the legal issues related to the discontinuation and abandonment of pipelines prior to the enactment of Bill 13, see: Alberta, Pipeline Abandonment Legal Working Group, Legal Issues Relating 10 Pipeline Abandonment: A Discussion Paper (May 1997), online: EUB <www.eub.gov.ab.ca/cyberDOCS30/Libraries/Defalut-Library/common/frameset.asp?> (date accessed: 3 October 2001). See also The Report and Recommendations of the Orphan Facilities. 
of a pipeline or part of a pipeline in the manner prescribed by the regulations, whether or not the pipeline or part of the pipeline is removed."

Prior to the changes introduced by Bill 13 , references to discontinuation and abandonment were found throughout the Pipeline Act, but there were no express duties in this regard. New sections have now been added that explicitly set forth the obligations to discontinue and abandon pipelines in Alberta. ${ }^{65}$ These are ss. 28.1 to 28.6.

Section 28.1(1) of the Pipeline Act sets forth the legal duties relating to the discontinuation and abandonment of a pipeline as follows: "A license ${ }^{66}$ shall discontinue or abandon a pipeline when directed by the Board or required by the regulations." The definition of licensee has been amended by Bill $13^{67}$ to mirror that in the OGCA. According to s. I(1)(i) of the Pipeline Act, a licensee "means the holder of a licence according to the records of the Board [EUB], and includes a trustee or receiver-manager of property of a licensee."

Pursuant to s. 28.1(1), the EUB now has specific authority under the Pipeline $A c t$ to order a licensee to discontinue or abandon its pipelines. Moreover, s. 28.1(2) clarifies that the EUB may order the discontinuation or abandonment of a pipeline where it considers this to be necessary "in order to protect the public or the environment." Other than the licensee, no other party is named in the Act as having a duty to discontinue or abandon a pipeline.

\section{B. When and How to Discontinue and Abandon}

To date, the Pipeline Regulation ${ }^{68}$ does not contain specific provisions for when a licensee must discontinue or abandon a pipeline. The only sections that deal with discontinuation and abandonment are ss. 60 to 68 , which deal with various matters concerning applications to the EUB for its consent to discontinue or abandon a pipeline. Under former ss. 32 and 33 of the Pipeline Act, a licensee was prohibited from discontinuing or abandoning a pipeline without the consent of the EUB. These sections have, however, been repealed by Bill $13,{ }^{69}$ rendering the current regulations of little application. $^{70}$

Given the changes to the Pipeline Act by Bill 13, new and revised regulations concerning when and how licensees are required to discontinue and abandon pipelines will

Bill 13, supra note 1, s. 2(17).

The former system of permits to construct and licences to operate under the Pipeline Act has been amended by Bill 13. All references to a permit in the Act have been replaced by licence, which is now defined in $\mathbf{s .} 1(\mathrm{l})(\mathrm{h})$ as "a licence to construct and operate a pipeline under this Act."

Supra note 1, s. 2(2)(d).

Alta. Reg. 122/87.

Supra note 1, s. 2(21).

Instead of prior approvals, licensees are now required to notify the EUB upon the completion of any discontinuation or abandonment. See: "Notification Requirements for the Discontinuation and Abandonment of Pipelines and the Abandonment of Facilities" (24 October 2000). ID 2000-09 (EUB). 
likely be forthcoming in the near future. Section 3(1)(e.1), added by Bill 13, ${ }^{71}$ now clarifies that the EUB may make regulations

respecting the discontinuation, abandonment and removal of pipelines, including the circumstances under which a pipeline must be discontinued, abandoned or removed, the timing of such discontinuation, abandonment or removal and the manner in which discontinuation, abandonment and removal are to be carried out.

\section{Continuing LiabiLity}

Also added by Bill 13 to the Pipeline Act is s. 28.3, which directly addresses the issue of continuing liability of the licensee after the abandonment of a pipeline. This section mirrors s. 20.4 of the OGCA. Section 28.3 of the Pipeline Act states as follows:

Abandonment of a pipeline does not relieve the licensee from the responsibility for further abandonment or other work with respect to the same pipeline or part of a pipeline that may become necessary, or from the responsibility for the costs of the further abandonment or other work.

\section{Discontinuation and Abandonment by the EUB}

Section 28.2 of the Pipeline Act now expressly grants the EUB the power to discontinue or abandon a pipeline on its own motion where there has been a failure to do so in accordance with the Board's direction or the regulations. In addition, the EUB may authorize any person to discontinue or abandon the pipeline on its behalf.

Other provisions added to the Pipeline Act in this regard mirror those found in the $O G C A$. Under s. 28.6 where a licensee, the EUB, or a person authorized by it carries out discontinuation or abandonment operations of a pipeline, that party "is entitled to have access to and may enter on the land and any structures on the land concerned for the purposes of carrying out" these operations. Section 28.5 empowers the EUB to "sell or dispose of any installation or material found on the site or taken from the pipeline" where the abandonment of a pipeline has been conducted by the Board or by any person it has authorized. The section also sets out how any money obtained from the sale is to be applied.

\section{E. Costs of Discontinuation AND Abandonment}

Unlike the $O G C A$, the Pipeline Act does not contain a general provision that speaks to the issue of who will pay the costs of discontinuing or abandoning a pipeline. Where a pipeline is discontinued or abandoned by the EUB under s. 28.2, however, s. 28.4(1) of the Pipeline Act allows the Board to determine the discontinuation or abandonment costs and to prescribe a time for payment of these costs. Sections $1(1)(a .01)$ and $1(1)(a .3)$ define these costs as "the reasonable costs actually incurred" in the discontinuation or abandonment of a pipeline. Pursuant to s. 28.4(1)(b) of the Act, the licensee of the pipeline shall pay the costs determined by the EUB. 
Unless the Board directs otherwise, a licensee who fails to pay the costs determined by the EUB within the time period prescribed must pay a penalty equal to 25 percent of those costs (s. 28.4(2)). Pursuant to s. 28.4(3), these costs, together with any applicable penalty, constitute a debt payable to the EUB. Section 28.4(4) of the Pipeline Act further provides that the EUB's costs order may be filed with the Court of Queen's Bench and, once so filed, may be enforced as a judgment of that Court.

\section{F. Personal accountability}

A mirror image to s. 95.1 of the OGCA has been added to the Pipeline Act by Bill $13{ }^{72}$ Section 51.1 of the Pipeline Act is virtually identical in its terms to s. 95.1 of the $O G C A$ (except that each $A c t$ references the other) and allows the EUB to restrict or control the activities of licensees (and approval holders) who are controlled by noncompliant individuals.

\section{LIABILITY FOR RECLAMATION OF Wells, FaCilities, and Pipelines}

The obligation to carry out conservation and reclamation activities is set forth in Part 5 of the EPEA. According to s. 2 of the Conservation and Reclamation Regulation, ${ }^{73}$ the objective of this part of the EPEA "is to return specified land to an equivalent land capability" upon the completion of certain operations. Equivalent land capability "means that the ability of the land to support various land uses after conservation and reclamation is similar to the ability that existed prior to an activity being conducted on the land." The individual land uses do not, however, have to be identical. ${ }^{74}$

\section{A. Duty to Reclaim Pursuant to the EPEA}

The statutory duty in regard to reclamation is found in s. 122(1) of the EPEA. This section requires an operator to conserve ${ }^{75}$ and reclaim specified land and to obtain a reclamation certificate in respect of that land. Section $\mathrm{l}(\mathrm{t})$ of the $C \& R$ Regulation defines specified land as including land "that is being or has been used or held for or in connection with" the construction, operation or reclamation of a well, oil production site, battery, pipeline, or plant. Also included is land that is being (or has been) used in connection with the conduct or reclamation of exploration operations for oil sands. Expressly excluded is land used for agricultural or residential purposes (s. 119(f), EPEA).

As noted, the EPEA places the obligation to reclaim specified land upon an operator. Section 119(b) defines this term very broadly as including all of the following parties:

72 Supra note 1, s. 2(30).

73 Alta. Reg. $115 / 93$ [hereinafter C\&R Regulation].

$74 \quad$ lbid., S. I(e).

75 Conservation is defined in $\mathrm{S} . \mathrm{I}(\mathrm{I})$ as "the planning, management and implementation of an activity with the objective of protecting the essential physical, chemical and biological characteristics of the environment against degradation." 
an approval or registration holder who carries on or has carried on an activity on or in respect of specified land pursuant to an approval or registration,

(ii)

any person who carries on or has carried on an activity on or in respect of specified land other than pursuant to an approval or registration,

the holder of a license, approval or permit issued by the Energy Resources Conservation Board for purposes related to the carrying on of an activity on or in respect of specified land,

(ii.l1) a working interest participant in a well on, in or under specified land,

(ii.2) the holder of a surface lease for purposes related to the carrying on of an activity on or in respect of specified land,

a successor, assignee, executor, administrator, receiver, receiver-manager or trustee of a person referred to in any of subclauses (i) to (ii.2), and

a person who acts as principal or agent of a person referred to in any of subclauses (i) to (iii). ${ }^{76}$

The Schedule of Activities to the EPEA defines activity for the purposes of this provision. It includes: (a) "the construction, operation or reclamation of a plant, structure, or thing" for the manufacture or processing of either petroleum products or natural gas and its products; (b) "the drilling, construction, operation or reclamation of a well other than a water well"; (c) the construction, operation, or reclamation of a pipeline, a heavy oil site, an oil sands site or an oil production site; and (d) "exploration operations that result or may result in surface disturbance." 77

In the EPEA's definition of operator, s. 119(b)(i) references the fact that certain operations require an approval or registration under ss. 58 and 59 of the EPEA prior to being commenced. These are set forth in the Activities Designation Regulation. ${ }^{78}$ Only certain types of oil and gas activities are listed therein. The construction, operation or reclamation of an oil refinery, an oil sands processing plant, a heavy oil processing plant, a sour gas processing plant, and a sweet gas processing plant are all included. Also included are: (a) the operation or reclamation of an oil production site; (b) the construction or reclamation of a pipeline; and (c) the conduct of an exploration operation for oil sands. Although these provisions appear to capture a whole range of oil and gas operations, their scope is cut back significantly by the definitions in the regulation. These should be carefully consulted before a determination is made about whether an approval or registration is required under the $E P E A^{79}$

\section{Supra note 5.}

Ibid. Schedule of Activities.

Alta. Reg. 211/96.

The Approvals and Registrations Procedure Regulation, Alta. Reg. 113/93, sets out the procedure for applying for an approval or registration under the EPEA. Operators conducting certain activities that require an approval under the EPEA must also provide sufficient security to ensure completion of conservation and reclamation (s. 120,EPEA and ss. 16-17.1, $C \& R$ Regulation). The security is held in the Environmental Protection Security Fund until a reclamation certificate is issued to the 
Noticeably absent from the list of operations requiring approval or registration under the $E P E A$ is the construction, operation, or reclamation of oil and gas wells. But, as noted above, land that is used in connection with the construction, operation, or reclamation of a well is specified land and must be reclaimed pursuant to s. 122(1) of the EPEA. The definition of specified land captures land that is involved in most oil and gas operations whether or not that operation requires prior approval or registration under the EPEA.

Where an approval or registration is not required under the $E P E A$, the second definition of operator in s. 119(b) applies to make any person who carries on (or has carried on) an activity on or in respect of specified land liable for reclamation. Clearly, this language suggests potential liability for past operators long after their involvement with the site may have ceased.

With respect to the inclusion of working interest participants in subclause (ii.11) of the definition of operator, two points should be made. First, the provision specifically refers to working interest participants in a well only. There is no mention of other facilities. Second, s. 119(j) of the EPEA defines working interest participant as a person "who owns or controls all or part of a beneficial or legal undivided interest in a well under an agreement that pertains to the ownership of that well." With its reference to control, this definition is now broader than the revised definition of a working interest participant under the $O G C A$.

In summary, the duty to reclaim specified land is cast broadly upon a number of parties who fit the definition of operator in s. 119(b) of the EPEA. Section 125(1) of the EPEA empowers an inspector to issue an environmental protection order ("EPO") "regarding conservation or reclamation to an operator directing the performance of any work or the suspension of any work ... necessary in order to conserve and reclaim specified land."

The EPEA does not, however, state whether any of the categories in the definition of operator takes precedence over any of the others and, if so, in what circumstances; nor does the $A c t$ provide any direct guidance for choosing amongst the various parties listed. Where a reclamation EPO is directed to more than one person, s. 226(1) states that "all persons named in the order are jointly responsible for carrying out the terms of the order and are jointly and severally liable for the payment of the costs of doing so."

\section{B. The Practice in Alberta}

Despite the potential for liability for reclamation to be imposed upon a number of parties under the EPEA, AENV has adopted a more restrictive approach in practice. In February 1998 AENV issued an information letter with the intention of clarifying who it will consider to be an operator for purposes of compliance and enforcement action in regard to reclamation under the $E P E A A^{80} C \& R / I L / 98-1$ applies to oil and gas wells, oil

operator.

st AENV, Conservation and Reclamation Information Letter C\&R/L/98-1, "Compliance and Enforcement Approach for Conservation and Reclamation of Oil and Gas Activities" (February 1998) [hereinafter $C \& R / L 98-I]$. 
production sites, batteries, pipelines, and any facilities associated with these operations (for example, access roads, borrow pits, and offsite sumps).

After citing the broad definition of operator found in s. 119(b) of the EPEA, $C \& R / I L / 98-I$ states AENV's adopted policy: "where an EPEA approval is in place, the approval holder will be considered the operator." ${ }^{81}$ However, where no EPEA approval has been issued (for example, in the case of an oil and gas well)

the EUB licensee will be the first to be considered the operator for conservation and reclamation compliance and enforcement issues because:

- industry standard practice is to hold the licensee responsible;

- EUB standard practice is to hold the licensee responsible; and

- operators can be tracked through existing EUB records rather than requiring AENV to develop a separate records system. ${ }^{82}$

Given this policy, $C \& R / I L / 98-1$ cautions that, as far as reclamation obligations are concerned, "it is important for a company to ensure that any sale [of oil and gas wells] is in fact registered with the EUB." ${ }^{83}$ When a company sells or divests pipelines, wells, and associated facilities, the licensee will continue to be considered the operator for reclamation liability "until the transfer of the licence has received the written consent of the EUB and the licensee name has been changed in the EUB database." 84 Notwithstanding this approach, $C \& R / I L / 98-I$ states that the full range of the definition of operator in the EPEA "may be used to select one or more operators based on the facts available to the department [AENV] or through information supplied by the licensee."

To date, two decisions of the Environmental Appeal Board ("EAB") have considered the application of AENV's practice of holding the current EUB licensee liable for reclamation: Sarg Oils Ltd. v. Alberta (Department of Environmental Protection) ${ }^{86}$ and Gammon Resources Ltd. v. Alberta (Department of Environmental Protection). ${ }^{87}$ In both, reclamation EPOs had been issued by AENV to the last licensee on record with the EUB. The last licensee in each case argued that other available parties who fell within the definition of operator in s. 119(b) of the EPEA should also have been held liable for reclamation. In particular, it was submitted that AENV should have considered imposing liability upon prior operators of the well sites given that they, and not the current

\footnotetext{
Ibid. at 1.

Ibid.

lbid.

Ibid.

Ibid.

[1996] A.E.A.B.D. No. 15, online: QL (AEAB) [hereinafter Sarg Oils]. Sarg Oil Ltd.'s appeal from AENV's issuance of a number of reclamation EPOs was first decided by the EAB on May 11, 1995: Sarg Oils Ltd. v. Alberla (Department of Environmental Protection), [1995] A.E.A.B.D. No. 4, online: QL (AEAB). However, a successful judicial review application followed and the matter was sent back to the EAB for reconsideration: Sarg Oils Lid. v. Alberta (Environmental Appeal Board) (1996), 185 A.R. 118 (Q.B.). For proceedings by the EUB to recover its costs for the abandonment of the wells involved, see: The Energy Resources Conservation Board v. Sarg Oils Ltd. (1998), 236 A.R. 298 (Q.B.), currently under appeal. [1996] A.E.A.B.D. No. 13, online: QL (AEAB).
} 
licensees, were primarily responsible for causing the damage that now needed to be cleaned up.

In dismissing these arguments, the EAB approved of AENV's practice of holding the last licensee on record with the EUB liable for reclamation. In its view, this practice is reasonable and is generally understood and supported by industry. Moreover, it makes good sense as a matter of fiscal and administrative policy: "If, in addition to the ... licensee of record, others were required to be held responsible for ... reclamation, records would have to be kept showing who had been operators." To allow an equitable distribution of liability, "those records would have to show how much work each [operator] had done and possibly how much production each had realized." According to the EAB, "such a situation could result in chaos in the industry, administrative logjams and extensive litigation." ${ }^{188}$

AENV's practice is indeed simple and convenient from the department's point of view. It also promotes certainty and predictability within the industry. Still, the definition of operator and the language of s. 125(1) of the EPEA clearly require A.ENV to exercise its discretion when choosing amongst the number of different parties listed. A blanket application of the practice of holding the last EUB licensee liable for reclamation without considering the particular circumstances of a case might subject AENV to a charge of fettering its discretion. Moreover, one wonders whether such a blanket application would run counter to s. 2(i) of the EPEA, which states that one of the purposes of the $A c t$ is to recognize "the responsibility of polluters to pay for the costs of their actions." ${ }^{19}$

In summary, the $E P E A$ imposes a duty to reclaim specified land upon a number of parties. These include approval holders, EUB licensees, working interest participants, surface lessees, and others who carry on or have carried on oil and gas activities upon specified land. In practice, however, AENV has adopted a policy of imposing reclamation liability upon the current EUB licensee first before pursuing other parties. This practice has been upheld by the EAB in two decisions.

\section{When and How to Reclaim SPECIFIEd LaNd}

Although neither the $E P E A$ nor the $C \& R$ Regulation specify when an operator must reclaim specified land, s. $129(1)$ of the $E P E A$ provides that a surface lease or right of entry order cannot be terminated until a reclamation certificate is issued. This should provide an incentive to reclaim land upon the abandonment of oil and gas operations. In addition, numerous provisions in the EPEA empower AENV to order and direct reclamation activities.

With respect to how reclamation must be conducted, s. 122(2) of the EPEA states that it "must be carried out in accordance with: (a) the terms and conditions in any applicable approval, (b) the terms and conditions of any environmental protection order" issued under Part 5 of the EPEA, (c) "the directions of an inspector or the Director," and (d) as 
otherwise required by the $E P E A$. Along with the $C \& R$ Regulation, a number of AENV directives set forth the requirements for proper reclamation under the $E P E A .{ }^{90}$

\section{CONTINUING LiabiLity OF OPERATOR}

An operator's liability for reclamation under the EPEA does not cease once a reclamation certificate is issued. Pursuant to $\mathrm{s}$. 127 , the person holding the certificate may remain subject to an EPO that necessitates further reclamation work. Section 127(3)(b) of the $E P E A$ and s. 15 of the $C \& R$ Regulation do, however, place time limits on the extent of this continuing liability. The limitation periods depend on the nature of the activities undertaken on specified land. Where no approval was required in respect of the activity, no EPO may be issued "more than 5 years after the date of the reclamation certificate." Where a reclamation certificate was issued in respect of the construction, operation, or reclamation of a plant, however, the time limit for issuing an EPO is 25 years after the date of the certificate. ${ }^{92}$

\section{E. COSTS OF RECLAMATION}

Although Part 5 of the EPEA clearly sets forth a duty to reclaim, its provisions do not directly address the issue of liability for the costs of reclamation. ${ }^{93}$ Later in the $A c t$, however, several miscellaneous sections provide some guidance on this issue. As noted, s. 226(1) provides that all persons named in an EPO are jointly responsible for carrying out the terms of the order, but are jointly and severally liable for payment of the costs of doing so. Such costs include those incurred by AENV where it has had to carry out the necessary work in the face of a non-compliant operator pursuant to s. 231 of the EPEA. ${ }^{94}$ In short, where more than one party is named in an EPO, each party is liable for the total cost of reclamation.

These include: AENV, Conservation and Reclamation Information Letter C\&R/IL/95-3. "Reclamation Criteria For Wellsites And Associated Facilities - 1995 Update" (April 1995); ANEV, Conservation and Reclanation Information Letter C\&R/IL/96-2, "More Questions on the Wellsite Reclamation Criteria" (June 1996); ANEV, Conservation and Reclamation Information Letter C\&R/L/94-5, "Environmental Protection Guidelines for Pipelines" (July 1994); ANEV, Conservation and Reclamation Information Letter C\&R/II/94-6, "Environmental Protection Guidelines for Oil Production Sites" (July 1994); Alberta Environment, Code of Practice for Oil Production Sites (effective July 1, 1997) and Code of Practice for Exploration Operations (effective July 1, 1997).

" C\& R Regulation, supra note 73, s. 15(1)(a).

$1 / 2$ Notwithstanding these limitation periods, other provisions in the EPEA may apply to allow AENV to direct reclamation activities atter their expiry. In particular, s. 110(2) of the EPEA allows AENV to designate a site as contaminated at any time, notwithstanding the fact that a reclamation certificate has been issued for the land.

Only one provision in Part 5 of the EPEA (s. 127(4)) speaks about reclamation costs and it is of very limited application. It applies where AENV carries out further reclamation work after a reclamation certificate has been issued and does not issue an EPO in respect of that work. According to s. 127(4), the costs of carrying out this work are the responsibility of the Alberta government.

* Section 231 authorizes AENV to take whatever action is necessary to carry out the terms of an EPO that has not been complied with by the person named therein. Costs incurred by the government under this section are recoverable: (a) in a debt action against the person to whom the EPO was directed; or (b) by Ministerial order directing any person who purchases land to which the EPO relates to pay to the Minister instead of the vendor the amount owing in respect of reclamation costs. 
Section 226(3) modifies the scope of this provision where an EPO "is directed to a person acting in the capacity of executor, administrator, receiver, receiver-manager or trustee." In this case that "person's liability is limited to the value of the assets that person is administering unless the situation identified in the order resulted from or was aggravated by the gross negligence or wilful misconduct of the executor, administrator, receiver, receiver-manager or trustee." 95

Part III.C of this article noted the changes introduced to the $O G C A$ in regard to suspension and abandonment costs of wells and facilities. Along with these changes, Bill 13 has added reclamation costs to s. 20.5 of the $O G C A .^{96}$ Section $20.5(1)$ reads as follows:

Subject to subsection (2), the well or facility suspension costs, abandonment costs and reclamation costs must be paid by the working interest participants in accordance with their proportionate share in the well or facility.

As discussed above, subsection (2) authorizes the EUB to determine these costs and then requires that they be allocated to each working interest participant in accordance with their proportionate interest in the well or facility. The rest of s. 20.5 also applies to the payment of well or facility reclamation costs. These provisions: (a) impose a 25 percent penalty on a defaulting working interest participant; (b) create a debt payable to the party who undertook the suspension, abandonment, or reclamation; (c) create a debt payable to the EUB where it suspended or abandoned a well or facility; and (d) authorize the filing of an EUB costs order regarding suspension, abandonment, and reclamation costs with the Court of Queen's Bench.

Bill 13 also added a definition of reclamation costs to the $O G C A .^{97}$ Pursuant to $\mathrm{s}$. 1(1)(s.3), "'reclamation costs' means the reasonable costs actually incurred in the reclamation of a well or facility, and includes such costs associated with assessment for the purposes of applying for a reclamation certificate under the Environmental Protection and Enhancement Act." Reclamation is also now defined in the $O G C A^{98}$ and means reclamation within the meaning of the EPEA.

As noted in Part Il of this article, reclamation costs were brought within s. 20.5 of the $O G C A$ largely for purposes relating to the Orphan Fund. The intention was to create a one-window process for suspension, abandonment, and reclamation costs through the EUB. Although Bill 13 may have succeeded in attaining this procedural objective, the inclusion of reclamation costs in s. 20.5 of the $O G C A$ raises a number of questions when the provisions of the EPEA are kept in mind. ${ }^{99}$

"S EPEA, supra note 5.

*. Supra note 1, s. 1(15).

$"$ Ibid., s. I(2)(h).

"* In s. I(1)(s. 2), as added by Bill 13, ibid., s. I(2)(h).

r) It should be noted that the EPEA has not been amended in any way to reflect any of the changes $B i l l$ 13 made to the $O G C A$ in regard to reclamation costs. 
As noted above, the only provision of general application in the EPEA that speaks directly to the issue of payment of reclamation costs is s. 226(1), which provides for joint and several liability where AENV has issued an EPO naming more than one person as operator. Assuming a situation where a number of working interest participants were named in a reclamation EPO, this provision would conflict with the statement in s. 20.5(1) of the $O G C A$ that these parties are liable only to the extent of their proportionate interests in the well or facility. Further, if parties other than working interest participants were named in a reclamation EPO, it is not at all clear what the effect of s. 20.5(1) of the $O G C A$ would be given the joint and several liability provision in s. 226(1) of the EPEA.

Where a reclamation EPO has not yet been issued, however, the interaction between s. 20.5 of the $O G C A$ and the reclamation provisions in the EPEA may be less confusing if a clear distinction is made between the duty to reclaim and the obligation to pay for the costs of that reclamation. As noted above, other than s. 226(1), the EPEA does not speak directly to the general issue of the payment of the costs of reclamation. Consequently, where no EPO has been issued, it may be possible to conclude that the EPEA sets forth the duty to reclaim only, while s. 20.5 of the $O G C A$ fills in a missing gap with respect to the payment of costs in the context of oil and gas operations. Questions will still, however, likely remain as to whether the $O G C A$ was the appropriate legislation for doing so. Amendments to the $E P E A$ to mirror those in the $O G C A$ relating to reclamation costs would likely clear up any uncertainty in this regard.

\section{EXPANSION OF ORPHAN FUND}

Where a party responsible for suspension/discontinuation, abandonment, and reclamation costs is unavailable or insolvent, its share of costs may be covered by the Orphan Fund established under Part 11.1 of the $O G C A$. One of the most notable changes to the $O G C A$ by Bill 13 is the expansion of the scope of this fund beyond abandonment costs for orphan wells. As amended, the Orphan Fund now covers the suspension and reclamation costs of orphan wells as well as the suspension/ discontinuation, abandonment, and reclamation costs of other orphan facilities and pipelines.

Section 59(1) of the OGCA sets out the new purposes of the Orphan Fund as follows:

(a) to pay for suspension costs, ${ }^{\text {(I) }}$ abandonment costs ${ }^{101}$ and related reclamation costs in respect of orphan wells, facilities, facility sites and well sites where the work is carried out

(i) by the Board,

(ii) by a person authorized by the Board, or

(iii) by a Director or a person authorized by a Director in accordance with the Environmental Protection Enhancement Act;

I'1 Again, in the case of pipelines, this includes abandonment costs as defined in the Pipeline Act. 
(b) to pay for costs incurred in pursuing reimbursement for the costs referred to in clause (a) from the person responsible for paying them;

(c) to pay for a defaulting working interest participant's ${ }^{112}$ share of suspension costs, abandonment costs and related reclamation costs incurred by a working interest participant if the person who carried out the work has taken all reasonable steps necessary to collect that share and has been unable to do so;

(d) to pay for any other costs directly related to the operations of the Board in respect of the orphan fund. ${ }^{103}$

According to s. 59(2)(c), the EUB may authorize payment from the Orphan Fund for any of these purposes in accordance with the regulations. ${ }^{104}$

Despite the reference to orphans in purpose (a), above, this term in not defined in the $O G C A$. Rather, s. 59(2)(a) authorizes the EUB to designate wells, facilities, facility sites, and well sites to be orphans for the purposes of Part 11.1.

The definition of facility in s. 1(1)(i.2) of the $O G C A^{105}$ applies to this part of the $A c t$ with some significant modifications. Section 57(d) states that, for purposes of this part, facility includes a pipeline under the Pipeline Act, but does not include a number of other operations such as: (a) "a processing plant or processing plant site as defined in the Oil Sands Conservation Regulation"; (b) "a gas processing plant that has sulphur recovery and sulphur storage facilities"; (c) "an oilfield waste management facility"; (d) "a refinery as defined in the Pipeline Act"; and (e) oil or gas transmission pipelines. In addition, facility site and well site do not include any part of the facility or well site that has been designated as contaminated under s. 110 of the EPEA. Thus restrictions as to what the Orphan Fund covers continue to exist despite its expanded scope to facilities and pipelines.

With respect to purpose (c) of the fund, s. 59(2) empowers the EUB to deem to be a defaulting working interest participant any working interest participant who: (a) has an obligation under the $O G C A$ "to contribute towards suspension costs, abandonment costs or related reclamation costs"; (b) has not contributed to those costs as required by the $O G C A$; and (c) "in the opinion of the Board [EUB], does not exist, cannot be located or does not have the financial means to contribute to those costs as required" by the $O G C A$.

Section 60 clarifies, however, that a defaulting working interest participant is never released from any liability under the $O G C A$ in respect of suspension, abandonment, and related reclamation costs even after payment is made from the fund to cover its share. Moreover, pursuant to s. $60(\mathrm{~b})$, if a person who receives payment from the fund recovers

Pursuant to s. 57(c) of the OGCA, defaulting working interest participant means one that has been deemed to be so under $\mathrm{s}$. 59(2)(b) (discussed below).

Supra note 3.

The $O G C R$ have not yet been amended to reflect the expanded scope of the Orphan Fund. New and revised regulations are expected soon.

As added by Bill 13, supra note I, s. I(2)(d). 
all or part of the costs from the defaulting working interest participant, it must return the amount recovered to the fund.

\section{CONCLusion}

As this article has shown, Bill 13 has made significant changes to the regulatory framework applicable to liability for suspension/discontinuation, abandonment, and reclamation of oil and gas wells, facilities, and pipelines in Alberta. In particular, new statutory duties for suspension/discontinuation of wells, facilities, and pipelines have been introduced. Personal liability for abandonment costs has been replaced by a new type of personal accountability in regard to suspension/discontinuation, abandonment, and reclamation costs. And finally, the Orphan Fund has been expanded to include the costs of suspending/discontinuing, abandoning, and reclaiming orphan wells, facilities, and pipelines.

Questions still, however, remain. New and revised regulations are undoubtedly necessary to complement the legislative provisions introduced by Bill 13. In particular, these regulations will have to detail when and how suspension/discontinuation, abandonment, and reclamation of wells, facilities, and pipelines must be carried out. Legislative change may also, however, be required - this time to the EPEA. To delineate AENV's practice of holding the current EUB licensee liable for reclamation, and to clear up any confusion that has resulted from the introduction of reclamation costs to the $O G C A$, amendments to the EPEA may be necessary. 